\title{
Grateful Remembrances
}

\author{
Aleksey Arzamazov \\ FRC Kazan Scientific Center, Russian Academy of Sciences
}

I perfectly remember my first meeting with Tatiana Grigoryevna Vladykina. I had just arrived in Udmurtia and entered University. I studied Udmurt theatre and had joined a folklore group. Tatiana Grigoryevna had heard about me from my teacher, professor Vladykin, who had become my second father. She asked about my situation, how my studies were going, whether everything was all right. She has always been characterised by modesty and sensitivity, the ability to unobtrusively offer help and support.

My second flash of remembrance is of a trip to the ancient Udmurt village of Varkled-Bod'ya, situated in the Agryz district of Tatarstan. This two-day trip was in summer 2003, when I had just started the second year at university. As I come from a Russian metropolis I had not previously had the chance to get more closely in touch with the fascinating, but attractively dangerous world of the traditional belief and ritual. This trip was something of an initiation. After my first year living in Izhevsk, the Udmurt were still for me a terra incognita. Tatiana Grigoryevna opened the complex world of Udmurt spiritual culture for me, for well she understood that without a layer of knowledge it would be extremely 
difficult for me to work seriously with Udmurt material and to investigate the mytho-folklore vocabulary of the Udmurt. How many cultural and ethnographic discoveries were made in these days! Udmurt sacrificial priests loaded with the sounds and meanings of old prayers, silver coins at the bottom of the transparent river Varkled, the globeflowers, the Udmurt italmas flower opening to the clear sky, the 'heavenly gates' turned towards the clouds, ritual porridge, the forest covered with animal skulls... Many of my questions Tatiana Grigoryevna did not answer. And this silence hid a very deep pedagogical wisdom. I had to independently experience, explore the unknown, read folklore texts, reach the spiritual heights of the Udmurt sacred words while still being a student.

Tatiana Grigoryevna helped me a lot at the communication level. For me, a young man from the city, it was not easy to accept the Udmurt system of life. The compulsory presence at early morning lectures, the head-count at the beginning of the lessons, parents meetings at the faculty. None of this fitted my understanding of what university tuition was supposed to be. Tatiana Grigoryevna smoothed the rough edges; she explained how to behave properly and spoke with the teachers, endeavouring to convince them about my 'peculiarities'. Shortly, she attempted to get me to feel at home in this new system of everyday life at the faculty of Udmurt philology.

When I was in the second year, she had a great lecture cycle about Udmurt folklore. And she delivered her lectures in Udmurt. I had just started to absorb the rich and complex language of the Udmurt. I remember how I had to concentrate not so much about the lecture, but about Vladykina's constructions, her efficient Udmurt idiomatic turns. Her sophisticated Udmurt speech has always been a model for me. This is how a professor of an Udmurt university should speak her mother tongue. 
It was exciting to me to find my place in the world of Udmurt philology. As I then thought, I apprehended many things on the wing, but I behaved too confidently for a student. In my fourth year, I suggested to Tatiana Grigoryevna that I could deliver a course with her as co-lecturer, so we developed a programme for a special course called the Hermeneutics of the folklore text. Students as well as teacher were amazed and shocked: a student who delivers lectures with a professor. This had never happened. Vladykina did not pay attention to these rumours. She always supported what was useful to general interaction.

And what a fantastic supervisor. With her, I walked a long distance towards my professional growing, from the student's shy and at the same time arrogant interventions in scientific conferences for young scholars, up to serious monographs, my doctoral dissertation, and the serious status of leading research fellow at the Russian academy of Science. Her doctoral students adore her. And she always defended her students' interests.

Tatiana Grigoryevna is a marvellous hostess. I have had many happy opportunities to attend the 'Yakshur mansion'. How they receive their guests. This is stratospheric Udmurt hospitality quiet, sincere, based on the deepest knowledge of folk etiquette and traditions. The Vladykins' - Vladimir Emel'yanovich and Tatiana Grigoryevna - home in Yakshur is an amazing world for the happy few. Only, there are many of these happy few. Who has not been there? Scholars of international reputation, famous politicians, social activists and simple people from different towns and countries looking for advice. And in the kuala a fire burns and the welcome porridge is boiling...

To write about a person who is very dear, and with whom one meets regularly and has done for many years is not an easy task. Is it right to share one's impressions and remembrances? For me, this is a rhetorical question. One thing is clear: Tatiana Grigoryevna is 
a person who has played a very important role in my life. Со понна соль Бадӟьлм Tay! (For this, a huge thank you!)

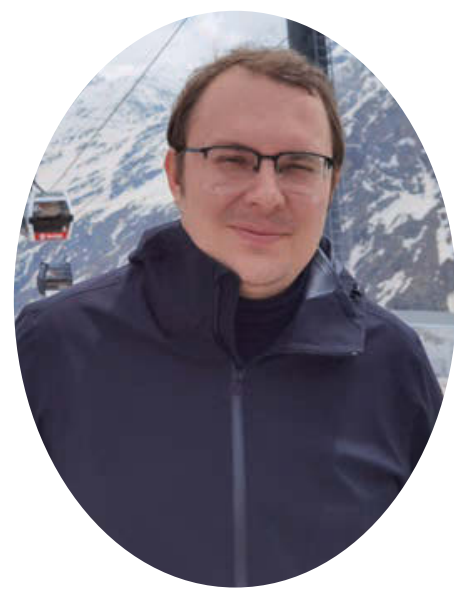

Aleksey Arzamazov (PhD hab) is a professor, leader of the laboratory of multifactorial analysis and cognitive philology at the FRC Kazan Scientific Center, Russian Academy of Sciences. He is a specialist in literature in general and Udmurt modern literature in particular.

e-mail: arzami@rambler.ru 